\title{
Political Determinants of Economic Exchange: Evidence from a Business Experiment in Senegal 10
}

\author{
Abhit Bhandari Institute for Advanced Study in Toulouse
}

\begin{abstract}
Economic growth requires confidence in the state's ability to enforce secure exchange. But when states selectively enforce rule of law, political considerations can moderate the trust that buyers have in sellers. I argue that political connections produce moral hazard in exchange because they introduce biases in expectations of judicial enforcement. Buyers avoid trade with politically connected sellers, and, in this context of unequal enforcement, formal contracts disproportionately protect politically connected buyers. To examine these features of connections and contracts, I created a sales business in Senegal and randomized whether employees signaled political connections and/or offered formal contracts during transactions. The results show that political connections decreased buyers' willingness to exchange. Formal contracts increased exchange, though primarily for connected buyers. These findings show that asymmetric political connections can impede daily trade and intensify economic inequalities in developing contexts, while simultaneously demonstrating the limits of state institutions for mitigating politically driven moral hazard.
\end{abstract}

Verification Materials: The data and materials required to verify the computational reproducibility of the results, procedures, and analyses in this article are available on the American Journal of Political Science Dataverse within the Harvard Dataverse Network, at: https://doi.org/10.7910/DVN/UIFXGX.

\section{Introduction}

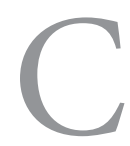

onfidence in basic forms of exchange is a fundamental building block for societies (Arrow 1972; North 1991). For an economy to function and grow, buyers must be confident that sellers will honor purchases and deliver the products promised to them. This is particularly true for modern markets where payment is due prior to product delivery, and where opportunities arise for seller moral hazard. For example, sellers may pocket payment and then deliver substandard goods, or may fail to deliver promised products altogether. Such seller moral hazard has become a salient problem for both firms and individuals in developing countries as emerging markets grow. Businesses cannot always rely on repeated trading relationships (e.g., Baker, Gibbons, and Murphy 2002), and consumers similarly engage in one-shot exchanges with sellers who offer delivery contingent on payment. Agreeing to buy and at least partly pay an unfamiliar seller before a good is delivered or its quality can be verified is a common feature of modern economies.

In countries with weak or selectively enforced rule of law, however, inequality in the application of rule of law can moderate buyers' confidence in sellers (North and Weingast 1989). These are places where who one knows can drastically affect business operations. Knowing someone in government can serve as a form of

Abhit Bhandari, Postdoctoral Research Fellow, Institute for Advanced Study in Toulouse, University of Toulouse Capitole, 1 Esplanade de l’Université, 31080 Toulouse Cedex 06, France (abhit.bhandari@iast.fr).

I thank the enumeration/sales team led by Fodé Sarr for their invaluable data collection effort, as well as the staff at APIX-Dakar, WARC, and the Communes of Médina, Golf Sud, and Pikine in Senegal for their assistance. For comments I thank Christopher Blattman, Jasper Cooper, Nikhar Gaikwad, Donald Green, Guy Grossman, Soeren Henn, John Huber, Macartan Humphreys, Kimuli Kasara, Sarah Khan, Horacio Larreguy, John Marshall, Lisa Mueller, Carlo Prato, Raul Sanchez de la Sierra, Tara Slough, Jonathan Weigel, Anna Wilke, Christopher Woodruff, and Lauren Young, as well as seminar participants at Columbia, Harvard, NEWEPS, Oxford, WGAPE, WZB, and Yale. This project was supported by the Private Enterprise Development in Low-Income Countries research initiative, the National Science Foundation (SES-1647457 and DGE 1644869), and the Abdul Latif Jameel Poverty Action Lab, and was approved by the Columbia Institutional Review Board. I acknowledge funding from the French National Research Agency (ANR) under the Investments for the Future program (Investissements d'Avenir, grant ANR-17-EURE-0010). The preanalysis plan for this study is registered with EGAP. 
protection from punishment: A seller's political connectivity grants relative impunity in the case of failure to deliver promised goods. Although there are certainly many benefits to possessing political connections (e.g., Szakonyi 2018), political inequalities between sellers and buyers may also stifle trade by exacerbating perceptions of seller moral hazard. Furthermore, this context of informal influences may complicate how citizens view the utility of state contracting institutions. Given the ubiquity of legal inequalities in developing countries, understanding how they affect propensities to engage in trade has significant implications for economic development.

In this article, I propose a theory of seller moral hazard in exchange in societies with selective rule of law. Due to the preferential treatment that political connections confer in these societies, buyers believe that politically connected sellers can break contracts with relative impunity. As a result, buyers avoid trade when sellers are politically connected and seek trade when sellers are less connected. In the context of these political inequalities, state-backed formal contracts may fail to mitigate risk for all types of buyers: If the successful enforcement of contracts is dependent on political access, they may only be useful to politically connected buyers. This theory implies that asymmetric political power shapes private-sector exchange and reinforces economic inequalities, and that political connections disrupt the function of formal institutions for contracting.

To study the impacts of political connections and contracts on private-sector exchange, I designed a field experiment in the urban environment of Dakar, Senegal. Its mixture of semireliable state institutions and salient informal influences made Senegal a fitting setting in which to test this theory. The field experiment sought to replicate a natural trading environment with real financial stakes and seller moral hazard. To that end, I created and legally registered a sales business, and hired employees to sell a mobile phone credit service with purchase options that captured different types of risk to 1,458 households. ${ }^{1}$ In a factorial design, I randomized whether, during transactions, my employees signaled their political connections and/or offered formal contracts. As outcomes, I measured whether respondents purchased any level of phone credit (where the risk was that the phone credit was not of the promised quality), ${ }^{2}$ as well as whether respondents purchased a level with delayed

\footnotetext{
${ }^{1}$ The business did not generate positive net profits; it was created solely for research purposes.

${ }^{2}$ Phone credit in Senegal can have varying levels of quality, which can be unclear upon delivery. I describe this in greater detail in the "Context" section.
}

delivery (which entailed the additional risk of potential nondelivery). To ensure that political connections were credible and consistent across employees, I partnered with three influential municipal councils in Dakar that agreed to hire and host my employees prior to the field experiment. During transactions, employees briefly mentioned their past employment at the councils to treated households as part of the extended introduction phase common to interactions in Senegal. To measure the political connections of buyers - as well as to parse the mechanisms by which the treatments operated-I implemented an endline survey among the sample several days after transactions occurred.

The results of the field experiment confirm that political connections can stifle exchange. Driven by the risk of substandard quality of products, overall purchase rates declined when sellers signaled their political connections. Taking buyers' political connections into account shows that reduced levels of trade with politically connected sellers were driven by politically connected buyers. These results are robust to interacting treatment with covariates that are correlated with buyer political connections, as well as to buyer-seller coethnicity and coreligiosity, the primary competing explanations of nonstate contract enforcement in markets like Senegal's. I also rule out the possibility that the political connection treatment operated by affecting the perceived competence or quality of sellers. Rather, sellers' political connections affect buyers' perceived recourse options: Successfully resolving a contract dispute is a more difficult prospect when the opposing party is politically connected.

The results also show that formal contracts substantially increased propensities to trade, particularly with purchases involving delayed delivery. This finding is somewhat surprising in that it demonstrates that formal contracts can mitigate risk and boost confidence in exchange even in markets with weak norms of enforcement. But exploring this result more deeply reveals a less rosy picture: The positive effects of formal contracts were driven by buyers who were politically connected themselves. Offering formal contracts had a substantially smaller effect on unconnected buyers' confidence in exchange. This finding suggests that formal contracts may be useful primarily for already-privileged citizens in societies with selective rule of law. In these contexts, state institutions may counterproductively perpetuate inequalities in private-sector exchange.

Overall, these results offer suggestive evidence that political connections can stifle private-sector exchange, and show that formal contracts favor the powerful under weak rule of law. This article thus makes several contributions. First, this project shows partial equilibrium 
effects for how individualized political connections can constrain private-sector growth, whereas existing work on political connections tends to emphasize other dimensions along which these connections can be profitable (e.g., Roberts 1990; Fisman 2001; Khwaja and Mian 2005; Faccio 2006). These studies condition on firms that already exist or on exchanges that already occurred. My findings, by contrast, provide evidence that political connections may prevent deals from occurring in the first place, implying that extant work may suffer from selection bias and mischaracterize the value of political connections. Furthermore, there has been a dearth of evidence connecting individualized political connectionswhich serve different purposes than firm-level political connections and thus operate through different theoretical channels - to private-sector economic outcomes in modern, urban markets. I provide experimental evidence of this impact, carefully manipulating seller moral hazard via the design-based innovation of creating and operating a business to elucidate key aspects of the theoretical dynamic. This article thus builds the evidence base for an important yet underexamined mechanism.

Second, I show that political connections influence trade even when controlling for established theories for social enforcement in sub-Saharan Africa like coethnicity and coreligiosity (Grimard 1997; Sanchez de la Sierra 2018). Political connections are nonascriptive, vary dynamically over time, and critically shape even demographically homogeneous societies. I thus argue that political connections merit study as a variable separate from other forms of social group enforcement that rely on mechanisms such as in-group pressure and reputation costs (Fearon and Laitin 1996; Habyarimana et al. 2007). My findings suggest that political connections operate through an alternate mechanism: legal system bias. Political connections may help to explain unequal development in the myriad societies where ethnicity is not a salient political dimension (e.g., Posner 2004).

Finally, I provide evidence for the impact of institutions on private-sector economic growth in states with weak rule of law. It is striking that contracts can increase confidence in exchange in Senegal, despite its reputation for weak contract enforcement. The results of this article suggest that, even in trying environments, people do believe in the state to some degree. And although existing work suggests that institutions are important because they facilitate trade and improve growth prospects (e.g., North 1991; Acemoglu and Johnson 2005), I add nuance by pointing to important distributional implications that are likely to enhance inequalities. I show that formal contracts can accentuate power differentials, and may thus fail to protect nonconnected citizens in societies where recourse options depend on political connections. These findings demonstrate that individual-level political connections can impede trade and limit the effectiveness of legal institutions for growth.

\section{Theory}

Existing work has shown that the state can enforce secure exchange (e.g., North and Weingast 1989) or that enforcement equilibria can emerge in the absence of cooperative state institutions (e.g., Greif 1989). ${ }^{3}$ However, in much of the world, particularly developing democracies, states have the capacity to enforce contracts and institutions are generally cooperative, but state agents are biased in the application of rule of law toward certain parties (Holland 2016; North 1990). Those who possess connections to people in power receive preferential treatment, including in the business environment. This setting can give rise to buyer moral hazard (Sanchez de la Sierra 2018) as well as seller moral hazard-pocketing payment and delivering substandard products or failing to deliver goods altogether. In this section, I develop a theory of seller moral hazard, outlining the roles of both sellers' political connections and formal contracts as well as how buyers' connections might moderate their effects.

\section{Seller Political Connections and Formal Contracts in Exchange}

Political connections are invaluable to firms when states selectively enforce the rule of law. Politically connected firms amass greater profit (Fisman 2001; Szakonyi 2018), achieve larger market valuations (Faccio 2006), and gain access to preferential state financing (Khwaja and Mian 2005). Dealing with politically connected firms can thus offer lucrative opportunities for potential business partners, including access to preferred markets, better capital, and a launching pad for developing one's own political connections. However, the relevance and probability of realizing these advantages are different for individuals than for firms. Although firms might value access to new markets, for example, this benefit is irrelevant to individuals engaging in one-shot exchanges with businesses. And even though individuals have incentives to develop their own political connections, they are unlikely to do so by trading with firm representatives they will never meet again. This is especially true of the types of trade

${ }^{3}$ See Online Appendix Q (p. SI12) for more discussion of the literature on commitment problems in exchange. 
that I focus on in this article, increasingly common in modern economies: one-shot exchanges involving seller moral hazard.

For individual buyers, the risks of trading with connected sellers often outweigh the potential benefits. Buyers are hesitant to purchase from politically powerful sellers because connected sellers are able to break contracts with relative impunity: The state's selective application of the rule of law enables connected people to escape punishment more easily than nonconnected people ( $\mathrm{Lu}, \mathrm{Pan}$, and Zhang 2015). In disputes with state-backed sellers, buyers expect the state-either in the form of courts or the more commonly used police and local mediatorsto enforce in favor of politically connected sellers (Frye 2004). Politically connected parties are also more likely to benefit from better access to and preferential enforcement from nonstate institutions (Bhandari 2020). Thus, because of the moral hazard they produce, sellers' political connections may stifle exchange.

Hypothesis 1: Sellers' political connections decrease the likelihood of exchange.

State-backed formal contracts could mitigate some of these moral hazard concerns. Contracts provide proof that a deal occurred, specify the responsibilities of the exchanging parties, and safeguard against hazardous exchanges (Williamson 1985). In large societies and economies, contracts can serve as third-party enforcement mechanisms that enable exchange to occur (Dixit 2003). Empirically, formal contracts have been shown to increase trade by improving agents' confidence in the trustworthiness and enforceability of exchange (Sanchez de la Sierra 2018). Assuming some level of rule of law and function of enforcement institutions, we might thus expect contracts on the margins to boost confidence in trade. But in countries with weak rule of law, this effect is not a given and varies depending on confidence in the formal institutions backing exchange (Poppo and Zenger 2002).

Hypothesis 2: Formal contracts increase (do not have an effect on) the likelihood of exchange.

\section{The Moderating Role of Buyers' Political Connections}

I argue that the advantages of political connections in navigating the enforcement system accrue not only to sellers with connections, but also to politically connected buyers. Because connected buyers can preferentially access enforcement institutions-cutting through the red tape that holds up the majority of citizens_-and benefit from the bias of these institutions, connected buyers have powers that unconnected ones do not. A buyer's political connections might thus mitigate concerns of seller moral hazard and factor into the decision calculus to engage in trade.

Asymmetric buyer-seller political connections may similarly moderate perceptions of seller moral hazard and propensities to exchange. During transactions characterized by seller moral hazard, buyers can assess power differentials and make decisions to trade accordingly. ${ }^{4}$ Holding fixed the terms of a given deal, we should expect a lower likelihood of trade when sellers are more powerful than buyers. Correspondingly, buyers are more likely to exchange when they have outsized influence relative to sellers. In situations where buyers are on similar enforcement playing fields, the predictions are less clear. When buyers and sellers are both unconnected, buyers may assume the worst about sellers' potential connections and thus choose not to exchange. When buyers and sellers are both connected, the playing field is relatively equal in terms of enforcement and buyers may choose to trade, though not as much as they would if sellers were unconnected. Table 1 summarizes these theoretical predictions.

Hypothesis 3: Buyers are more likely to exchange when they are politically connected and sellers are not, and less likely to exchange when sellers are politically connected and they are not.

In the context of these political power dynamics, do formal contracts differentially moderate the perception of seller moral hazard for connected and unconnected buyers? Formal contracts draw their power from the authority of the state. Politically connected citizens receive privileged access to and treatment from state institutions, and thus the power to have contracts enforced is concentrated in the state-backed party. In the buyer-seller theoretical framework, politically connected buyers are more likely to have contracts enforced in their favor than unconnected buyers, holding constant the seller's political connections. Thus, formal contracts are more likely to mitigate perceptions of seller moral hazard for connected buyers and should disproportionately motivate connected types to exchange. In this way, the use of formal institutions like formal contracts may

\footnotetext{
${ }^{4}$ Sellers may possess incentives to hide their political connections, and in some cases this may mitigate the costs of being perceived as connected. However, in developing democracies where informal influences are rampant, buyers may already have preconceived notions of sellers' connectivity, or can make these assessments based on extended introductions.
} 
TABle 1 Theoretical Predictions Under Asymmetric Political Connections

\begin{tabular}{llll}
\hline & & \multicolumn{2}{c}{ Buyer is politically connected } \\
\cline { 3 - 4 } & & \multicolumn{2}{c}{ No } \\
\hline Seller is politically connected & No & Intermediate probability of purchase & High probability of purchase \\
& Yes & Low probability of purchase & Intermediate probability of purchase \\
\hline
\end{tabular}

unintentionally exacerbate inequality in environments with selectively enforced rule of law.

Hypothesis 4: Formal contracts increase the likelihood of exchange for connected buyers more than unconnected buyers.

\section{Context}

\section{Rule of Law and Methods of Enforcement}

Senegal is a multiparty democracy in West Africa. Despite its democratic tendencies, however, Senegal's rule of law institutions remain weak. The World Bank ranks Senegal at 140 of 190 economies in terms of overall ease of doing business, and 142 in enforcing contracts. Its judiciary is based on French civil law, generally considered inferior to common law systems for securing property rights and growth in Africa (Joireman 2001), and its legal institutions suffer from excessive procedural formalism, limited judicial independence, and high costs and waiting times (Kondylis and Stein 2018). This results in negative perceptions on the part of citizens of the judiciary's accessibility.

Despite these weaknesses, Senegalese citizens place a relatively high degree of trust in legal institutions, at least when politically connected parties are not involved. ${ }^{5}$ Still, most citizens are unlikely to use high-level courts or lawyers to settle small-scale contract disputes-the type this project probes-due to the significant financial and time costs. Citizens typically first attempt to resolve petty disputes amicably, which involves contacting the defector (either directly or via shared social networks) and coming to an agreed-upon resolution. ${ }^{6}$ If this fails, the affected party may involve the local police or courts. These means of enforcement become complicated by political connections, however.

\footnotetext{
${ }^{5}$ See Online Appendix Figure J3 (p. SI8).

${ }^{6}$ For a discussion of social forms of enforcement in Senegal, see Online Appendix R (pp. SI12-SI13).
}

\section{Political Connections in Exchange}

A commonly held view in Senegal is that political connections lead to preferential treatment at all levels of the state. With Senegal's often labyrinthine bureaucratic structures, knowing someone in power allows for quicker access, processing, and eventual success in matters involving the state. Connections reduce the massive amounts of red tape with which unconnected citizens must contend, and knowing even a low-level bureaucrat can enhance the chances of gaining preferential access to institutions. Getting one's foot in the door can be among the most difficult steps in the enforcement process, and even nondirect connections help to overcome this constraint via shared governmental networks. ${ }^{7}$ Political connections thus play a significant role in the business environment by determining access to means of enforcement. Indeed, citizens anticipate that enforcement will be biased toward the party with more political power even when nonstate resolution mechanisms are used.

The consensus of my sample was that political connections decrease the probability of punishment for contract breach. Approximately $76 \%$ of respondents stated that connections enable trading partners to escape punishment when they break contracts, and only $27 \%$ reported confidence in local courts' and police's ability to impartially enforce a contract when politically connected people are involved. Figure 1 shows the extent to which respondents believe that people with connections to councils, courts, and police are able to escape punishment during contract disputes. Overall, there is severe distrust in the enforcement process as it applies to politically connected sellers.

\section{Contracts, Transactions, and the Phone Credit Market}

A formal contract in Senegal typically takes the form of a written document that follows governmental standards

\footnotetext{
${ }^{7}$ For example, when asked how he resolved his past contract dispute, a respondent stated that his sister worked as a secretary at the local council, and was able to connect him to the local police chief who helped him to file the correct paperwork.
} 


\section{FIGURE 1 Connections and Perceived Impunity}

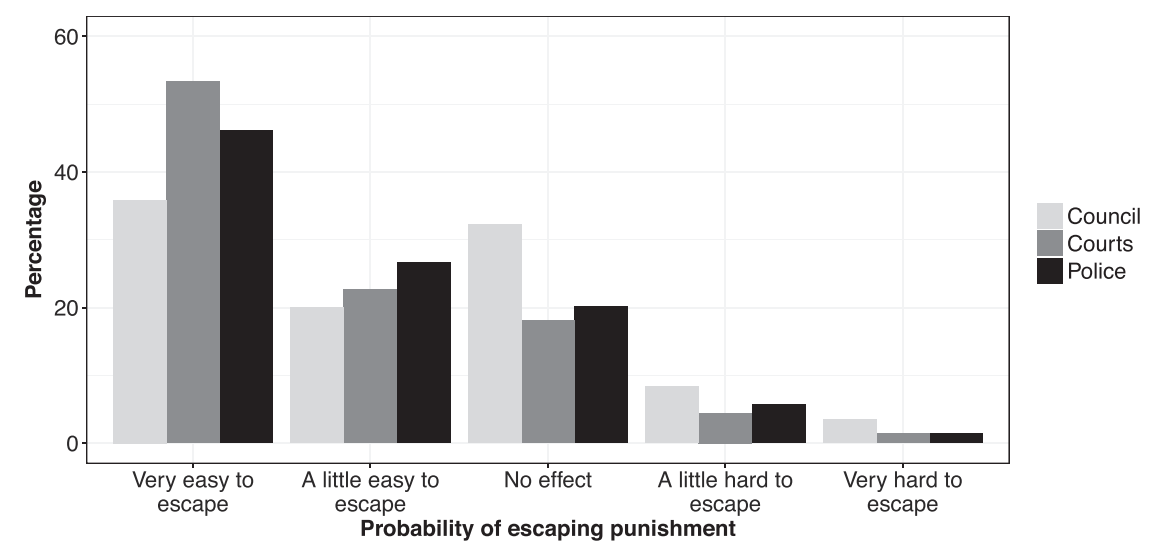

Note: Sample's responses when asked how political connections to the councils, courts, and police affect the probability of escaping punishment during contract disputes. $N=1,458$.

to be executable by local courts of law. Informal contracts are those that do not meet this criteria, and in practice are typically verbal agreements. In trade where delivery is made after payment, contracts serve as more than de facto receipts. Formal contracts include terms and conditions, delineate the contracting parties' responsibilities, and outline procedures in case of contract breach that make resolving disputes more streamlined.

Transactions with delayed delivery to households are not uncommon in Dakar, particularly in densely populated neighborhoods. Although typically this type of sale on credit at the household level has been done by informal traders, entrepreneurial growth in Senegal has led to an increase in direct-to-household sales by formalsector businesses. For example, $82 \%$ of respondents in my sample reported participation in door-to-door sales campaigns in the past, some of which are run by major telecommunications companies in the country. The marketplace for phone credit in Senegal lends itself to doorto-door sales. Few people receive phone credit through wireless subscription services. Rather, phone credit is purchased as required, either from ambulatory traders or from neighborhood kiosks. There is significant demand for mobile credit, and prices are disproportionately high relative to income, particularly in middle- to lower income neighborhoods. Buyers are thus keen on alternate methods for receiving phone credit, especially at competitive prices. Important for the research design of this project, phone credit in Senegal can have varying levels of quality. The major wireless companies typically provide bonus credit as an incentive for buyers to purchase, but this bonus credit is considered lower quality because its use is restricted. Thus, bonus phone credit that is just as good as "regular" credit is highly desirable, though the quality of this credit may not be immediately apparent upon purchase.

\section{Research Design}

I implemented a field experiment that allowed me to carefully manipulate seller moral hazard in order to test the effects of formal contracts and political connections on exchange. To ensure a natural trading environment, I created and registered a legal, formal-sector business in Senegal, and hired employees to offer a phone credit service via door-to-door sales in sample municipal districts. In a factorial design, I randomized whether employees signaled their political connections, as well as whether they offered formal contracts as part of the deal. This article thus takes a partial equilibrium approach to understand how connections and contracts affect propensities to exchange, holding other features of the seller and transaction constant. An endline survey was conducted several days after the transactions took place to measure buyers' political connections. The real economic environment and the panel structure of the data allow for the rare casual estimation of the effect of political connections and formal contracts on exchange based on political asymmetries in the trading dyad.

\section{Business Creation}

In preparation for the experiment, I undertook the process of creating and registering a formal business in Senegal. I completed the process in 2016 at APIX, Senegal's primary agency for the promotion of investment and major works, which is also home to Senegal's guichet unique 
(one-stop shop) for formalizing a business. ${ }^{8}$ After successfully formalizing the business, I received a unique business identification number called the NINEA, which is commonly understood in Senegal as proof that a business is formal. ${ }^{9}$

The business, called Porte-à-Porte Sénégal (Doorto-Door Senegal, or PAPS), offered discounted mobile phone credits. Mobile credit was chosen as the activity of interest for several reasons. First, this resembled common sales practices in Senegal, where ambulatory traders sell small items including discounted phone credit directly to households. ${ }^{10}$ As mentioned above, $82 \%$ of respondents in my sample said they had purchased items in similar door-to-door sales campaigns in the past. Second, there is high demand in Senegal for discounted mobile phone credit, which helped to minimize the likelihood of floor effects. Finally, the varying quality of phone credit in Senegal, as well as the ability for phone credit to be delivered remotely at a later date, allowed for varying two dimensions of seller moral hazard: the risk of substandard product quality and the risk of nondelivery. There is already a common distrust of the telecommunications company in Senegal whose credit PAPS sold, which further spurred respondents to consider the risk of the deal.

\section{Ethical Considerations}

This article is arguably the first to manipulate how businesses deploy political connections, which I was able to accomplish by creating an original business. Though operating a business enables testing heretofore untestable development-related hypotheses in a realistic trading environment, it raises important ethical considerations. These concerns include conducting research in a manner appropriate to the local context, avoiding the displacement of economic activity, and minimizing the misuse of public resources.

To ensure that this project conformed to the local context, I sought and gained approval from the Ministry of Scientific Research in Senegal, the three district governments in which I operated the business, and a research

\footnotetext{
${ }^{8}$ Despite the "one-stop" shop, registering the business required the acquisition of certain documents that are not centrally controlled. This required visits to a chef de quartier (neighborhood chief), police department, and government ministries.

${ }^{9}$ Online Appendix Figure A1 (p. SI2) shows a copy of the business registration.

${ }^{10}$ Though the formalized method my company used to sell credit at a discount was perhaps novel to some buyers, it is not unusual during Senegal's entrepreneurial boom in which small businesses have formalized previously informal practices.
}

center in Dakar with which I have a longstanding relationship. All approved the project, and the research institution confirmed that the project "does not go against cultural, social, or political norms in Senegal, and is in line with what is appropriate for research here." Because such transactions are commonplace for respondents in the sample districts, the IRB and Senegalese authorities agreed that respondents could be debriefed at the beginning of the endline survey, and although respondents were given the option to withdraw from the study at that point, none chose to do so. Furthermore, there was no deception in business practices, as all who paid for phone credit received the quality of credit they were promised on the date that they were promised.

To avoid displacing existing economic activity, I ensured the minimal number of transactions necessary to satisfy statistical power demands, and discussed the research plan with the three local governments where I conducted research activities. Sellers conducted transactions with only 486 respondents in each district from an average district population of around 165,000. Interviews with local businesses and purveyors of phone credit confirmed they were unconcerned by the prospect of displaced economic activity because of the limited reach and duration of the project. Finally, APIX understood that the business I registered was for research purposes, and confirmed that PAPS' creation was not displacing other registration activity or otherwise misusing public resources.

\section{Sample Selection and Partner Municipal Councils}

A key treatment arm in the experiment required sellers to signal their political connections to buyers. For ethical purposes as well as the interpretation of eventual results, I ensured employees possessed political connections that were credible and consistent across the team. To achieve this, I partnered with three influential municipal councils in Dakar, and arranged for my employees to work at these councils prior to data collection. These municipal units are the level of government with which the average citizen in Dakar interacts most frequently, and they have tremendous local influence across a range of political and economic dimensions. For the purposes of contract enforcement, being connected to the council enables access to officials at numerous state organizations via shared governmental networks; these connections open side doors to many enforcement institutions. Each of my employees performed a weeklong internship at a partner council. The typical internship consisted of rotating between the various divisions at the given 
council, gaining a sense of each division's activities, and meeting staff members throughout the council.

Of course, performing short internships with councils could result in a relatively weak type of political connection, so this design might serve as a hard test of the theory proposed above. Still, seemingly low-level political connections are important to daily life in Senegal, as they signal the types of networks and resources to which an individual has access, regardless of how small the connection may seem. Even casually knowing the right person can change one's dealings with bureaucratic structures entirely. Those without such connections do not have access to the same recourse options that connected individuals-especially those connected to powerful municipal councils-do in the event of contract breach. As demonstrated in a manipulation check later in the article, buyers considered my employees to possess legitimate political connections.

Because sellers had to work at the councils of the communes in which I implemented the experiment, I met with government administrators at communes that fit the following criteria: (1) densely populated communes inhabited primarily by middle- to lower income workers for whom baseline takeup of discounted mobile credit would be sufficiently high; 2) communes where household access would be relatively straightforward (e.g., not obstructed by large gates, as is common in the more affluent neighborhoods of Dakar); and (3) communes where household sales are commonplace enough such that door-to-door transactions would not be perceived as unusual. Of the five municipal governments I met with, three agreed to hire my employees and permitted research activities to occur: Golf Sud, Médina, and Pikine. I hired nine employees to work for my firm, and thus three employees worked at each council.

\section{Treatment Conditions}

The experiment deployed a factorial design with three treatment arms to test the effects of political connections and formal contracts on economic exchange. In the first arm, sellers signaled their municipal council political connections to buyers. They did so by briefly mentioning their former work experience at the beginning of transactions, during the lengthy introduction period that is common to household transactions in Senegal. ${ }^{11}$ Rather than recreate a general trading equilibrium, this treatment aimed to induce buyers to consider the implications

\footnotetext{
${ }^{11}$ Online Appendix B (pp. SI2-SI3) presents an outline of the transaction protocol that enumerators followed.
}

of sellers' political connections. To rule out the concern that the treatment may have appeared artificial or strange to buyers, the endline survey asked buyers about their skepticism; the evidence shows that suspicion was low and not affected by treatment (see Online Appendix Table N10, p. SI11).

In the second treatment arm, sellers included a formal contract as part of the deal. The contract contained key information about the terms of the deal, method of payment, and delivery. Critically, the contract also included a clause on the method of conflict resolution and procedures for recourse in the case of contract breach. ${ }^{12}$ If PAPS failed to deliver the quality or amount of mobile credit that buyers purchased, the contract stipulated that attempts would be made to resolve the dispute amicably before bringing the case before local courts. This mirrored the language of standard contracts in Senegal. Indeed, the contract was reviewed and approved by a Senegalese law firm, which deemed it to be executable in local courts of law. Sellers explained the contract during transactions, and briefly mentioned that the contract contained information about recourse options. In this treatment arm, buyers and sellers were both required to sign two copies of the contract in order to execute the deal, as is standard in Senegal; the buyer kept one copy, and PAPS kept the other.

For the third and final treatment arm, sellers again offered formal contracts as part of the deal, but in this arm the formal contract was optional. To mimic the transaction costs of contracting, buyers receiving this treatment could elect to have a formal contract for a marginal additional cost. This is consistent with the costs of contracting in Senegal, where, at the end of some transactions, sellers offer a receipt or contract at a very small fee. Sellers explained this fee as an administrative requirement due to the costs of contracting in the formal sector. Although there is a risk that some buyers may have found this option to be unusual, Online Appendix Table N10 (p. SI11) shows that, in line with expectations in Senegal, this treatment arm did not raise buyers' suspicions. The two formal contract treatment arms attempted to capture variation in the extent to which sellers constrain themselves with contracts; in some cases, they fully constrain themselves by requiring a contract to be signed, and in others, the formal contract serves more as a nonbinding signal. Table 2 summarizes the components of the factorial design and shows the six treatment groups.

\footnotetext{
${ }^{12}$ Online Appendix C (p. SI3) includes a translation of this clause.
} 
TABLE 2 Treatment Groups

\begin{tabular}{|c|c|c|c|c|}
\hline & & \multicolumn{3}{|c|}{ Contract availability } \\
\hline & & No contract & Contract (required) & Contract (optional) \\
\hline Signaled & No & Pure control & Required contract & Optional contract \\
\hline connections & Yes & Connection & Connection + required contract & Connection + optional contract \\
\hline
\end{tabular}

\section{Data Collection}

There were two main stages of data collection: (1) the transaction phase during which sellers sold the phone credit service and (2) an endline panel survey several days after transactions took place. During the transaction stage, sellers followed the randomization scheme as described in the next subsection and conducted doorto-door sales in the three sample communes. At the end of each transaction, sellers completed a self-administered survey in which they noted the questions buyers asked during transactions, as well as answered subjective questions about buyers' politeness, confusion, and suspicion. In total, sellers conducted transactions with 1,458 respondents.

Three to five days following the transactions in each district, enumerators administered an endline survey to sample respondents. Endline surveys were conducted by different enumerators than those who performed the original transactions, in order to minimize social desirability bias for questions about seller quality and competence, as well as to avoid awkwardness of being surveyed by someone previously associated with a business deal. Of the 1,458 buyers who participated in transactions, enumerators conducted the endline survey with 1,422 respondents. ${ }^{13}$

Critically, the endline survey included questions that measured buyers' political connections. Enumerators asked respondents about family, friends, and personal experience working at a variety of state institutions, including national government, councils, courts, and the police. ${ }^{14}$ I code respondents as politically connected if they report a connection. This follows from the understanding that in Senegal, possessing any political connection can improve enforcement probability relative to unconnected citizens, as even low-level connections

\footnotetext{
${ }^{13}$ Online Appendix Table G4 (p. SI6) shows that treatment does not predict differential rates of endline attrition. Covariates for missing respondents at endline were imputed using sample means; results throughout are robust to excluding these missing respondents.

${ }^{14}$ Online Appendix Table O11 (p. SI11) shows that buyers to whom sellers signaled political connections did not overreport their own political connections.
}

can help grant access to otherwise hermetic institutions. Figure 2 shows the percentage of the sample reporting political connections.

\section{Randomization}

I implemented a block randomized design wherein six geographically sequential sample households constituted a block, with all six treatment groups represented in each block. Blocks were thus essentially microneighborhoods, similar in both observable and unobservable street-level variation. To minimize the risk of spillovers between buyers, enumerators ensured a predetermined distance between households. ${ }^{15}$ Enumerators offered the deal to only one person per household to avoid withinhousehold spillovers. ${ }^{16}$ With 486 sample households in each of the three sample communes, the total sample consisted of 1,458 buyers. ${ }^{17}$

\section{Measurement of Primary Outcomes}

Sellers offered phone credit at competitive, discounted prices to incentivize buyers to consider purchasing. These prices were comparable to the discounts regularly promoted by the wireless company itself, with a key difference that PAPS' "bonus" credit was of higher quality: Although the wireless company's bonus credit is not eligible for transfers, subscription purchases, or internet access, the bonus credit that PAPS offered was as good as regular mobile credit and thus highly desirable. The discounted rates did not raise buyers' suspicions because they fit market expectations in Senegal; the only novel feature was the higher quality bonus credit, a believable promotion in the competitive phone credit market.

\footnotetext{
${ }^{15}$ Only $1.6 \%$ of respondents reported telling someone farther away than a next-door neighbor about the deal, and, because transactions were conducted rapidly within blocks, the threat of spillover effects was low.

${ }^{16}$ The household limit was explained to respondents as an administrative constraint due to the initial roll-out phase of the business.

${ }^{17}$ During an initial screening step, over $99 \%$ of respondents said they had a cell phone and were interested in discounted phone credit, and thus these logistical constraints are unlikely to affect the interpretation of results.
} 


\section{FIGURE 2 Percentage of Respondents with Connections}

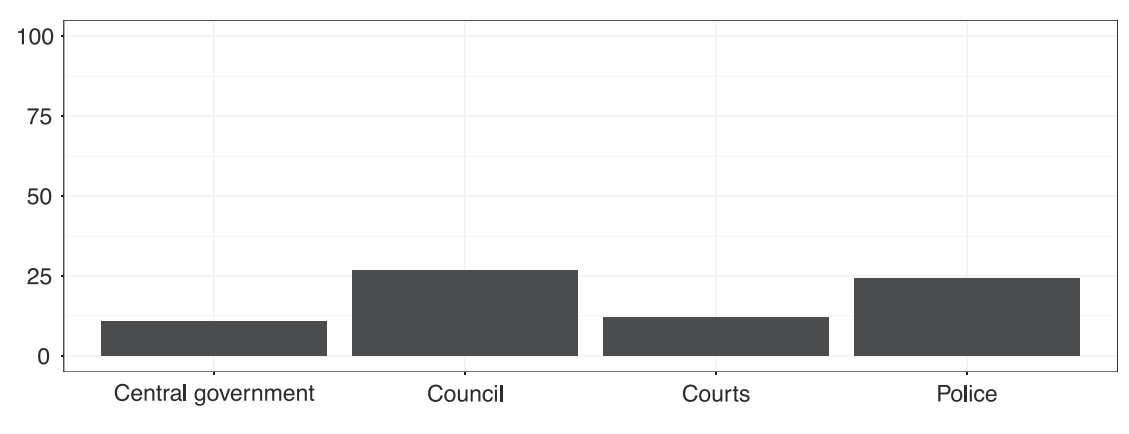

Note: Percentage of respondents reporting connections to the labeled political institution. $N=1,422$.

Buyers could choose from three purchase option levels that capture different types of risk. First, to receive the phone credit nearly instantly, buyers could pay 700 CFA and receive 1,000 CFA worth of credit. The primary risk to buyers of this simple exchange was that the bonus credit delivered could be of lower quality than sellers had promised, especially as this is difficult to detect until sellers may have already left the area. Second, to receive a greater amount of credit (1,500 CFA) at a cheaper price (500 CFA), buyers could opt for a second - and riskierlevel, for which credit delivery would occur 3 days after the transaction took place. ${ }^{18}$ This naturally required a greater amount of buyer trust in sellers, and attempted to mimic the typical hold-up problems in modern markets where nondelivery is a risk in addition to defective products. Although at first glance this delayed delivery may have seemed odd to buyers, sellers explained that the delay was due to administrative processing requirements that were part of the business model that enabled these competitive rates. These types of terms were not new to most buyers, the majority of whom had participated in similar sales with delay in the past. ${ }^{19}$ The third and final purchase option available to prospective buyers increased the risk by requiring a heftier sum (1,000 CFA) in order to receive the most phone credit (3,000 CFA), again with delayed delivery. The per capita daily income in the sample communes is approximately 1,500 CFA ( 3 USD), so these costs were significant to respondents. Table 3 sum-

${ }^{18}$ The difference in cost between the first and second levels was decided after extensive piloting; the framing of "less money for more credit" was rhetorically useful for inducing respondents to seriously consider the risk of the second level.

\footnotetext{
${ }^{19}$ The piloting prior to the experiment helped to ensure that the levels of the deal struck the correct balance of competitiveness and risk, as well as ensured that respondents were not taken aback by the nature of the delayed delivery. Indeed, as Online Appendix N (p. SI11) shows, respondents' overall skepticism of the deal itself was extremely low.
}

marizes the purchase options, and Figure 3 reports buyers' purchases.

I code the outcome in two ways, to distinguish between the different dimensions of risk presented by the purchase levels. First, to measure whether potential buyers were willing to engage in exchange at all, I create a binary indicator for whether respondents purchased any level of the deal. Second, to capture the higher risk behavior and the willingness to take on the added risk of nondelivery, I also create a binary indicator for whether respondents purchased the phone credit with delay. I present results for both outcomes throughout.

\section{Estimation}

I estimate average treatment effects (ATEs) with the following OLS specification: ${ }^{20}$

$$
\begin{aligned}
y_{i}= & \alpha+\beta_{1} \text { connection }_{i}+\beta_{2} \text { required } \text { contract }_{i} \\
& +\beta_{3} \text { optional cont ract }_{i} \\
& +\beta_{4}\left(\text { connection }_{i} \times \text { required } \text { contract }_{i}\right) \\
& +\beta_{5}\left(\text { connection }_{i} \times \text { optional contract }_{i}\right) \\
& +\gamma \mathbf{X}_{i}+\eta_{b}+\theta_{e}+\epsilon_{i},
\end{aligned}
$$

where $y_{i}$ is the indicator variable for purchasing at all or purchasing with delay, $\mathbf{X}_{i}$ is a matrix of covariates, $\eta_{b}$ are randomization block fixed effects, and $\theta_{e}$ are enumerator fixed effects. To estimate the marginal effect of each treatment arm, I remove the interaction terms. To estimate heterogeneous effects, I interact the relevant covari-

\footnotetext{
${ }^{20}$ To take account of the nonlinear nature of the purchase levels, I also present odds ratios from multinomial logistic regressions in Online Appendix S (pp. SI13-SI14), and to take account of the binary outcome coding, I present probit models in Online Appendix $\mathrm{W}$ (p. SI17). The multinomial and probit results yield similar conclusions to those in the main body.
} 
Table 3 Phone Credit Purchase Options

\begin{tabular}{lccll}
\hline $\begin{array}{l}\text { Purchase } \\
\text { level }\end{array}$ & $\begin{array}{c}\text { Cost } \\
\text { (CFA) }\end{array}$ & $\begin{array}{c}\text { Credits } \\
\text { received }(\text { CFA })\end{array}$ & $\begin{array}{c}\text { When phone } \\
\text { credit arrived }\end{array}$ & \multicolumn{1}{c}{ Type of risk } \\
\hline $\begin{array}{l}\text { Declined deal } \\
\text { No delay }\end{array}$ & - & - & - & Risk of substandard quality \\
Delay $(\$)$ & 700 & 1,000 & Several minutes & Risk of substandard quality and nondelivery \\
Delay $(\$ \$)$ & 500 & 1,500 & In 3 days & Risk of substandard quality and nondelivery \\
\hline
\end{tabular}

ate with the treatment terms. All tests in the article are two-sided unless preregistered as one sided. The models control for covariates that could affect acceptance of the deal, including age, education, employment status, whether the buyer was a student, and gender. To rule out competing theories of social enforcement, I also include interactive controls between treatments and buyerseller coethnicity or coreligiosity, which in Senegal are the dominant informal social institutions for enforcement (Cruise O’Brien 1971; Gottlieb 2017; Koter 2013). ${ }^{21}$ Additional information about control variables can be found in the balance table presented in Online Appendix E (p. SI5) as well as the summary statistics table in Online Appendix F (p. SI5).

\section{Randomization Validation and Manipulation Check}

As a heuristic for the randomization procedure's success, I estimate Equation (1) using individual covariates to show that respondent-level traits do not predict

${ }^{21}$ The seller team represented all of the major ethnic and religious groups of Senegal. treatment assignment. As shown in Online Appendix Table E2 (p. SI5), there is balance over eight covariates across treatment groups. The two-sided joint $F$-test of the restriction that each treatment group is indistinguishable from the others was rejected in only one case.

Important for the experiment was that the political connection signal successfully induced buyers to believe that sellers were connected. To that end, the endline survey included a question on whether buyers thought sellers were politically connected. Table 4 shows that treated respondents were 18.8 percentage points more likely to believe that sellers were politically connected, suggesting that the political connection signal was transmitted effectively.

\section{Results}

To test the effect of political connections and formal contracts on exchange, I first estimate ATEs. I then take account of buyers' political connections to examine how political power asymmetries affect exchange, as well as how buyers' connections moderate the perceived utility of formal contracts.

\section{FIGURE 3 Distribution of Buyers' Purchases}

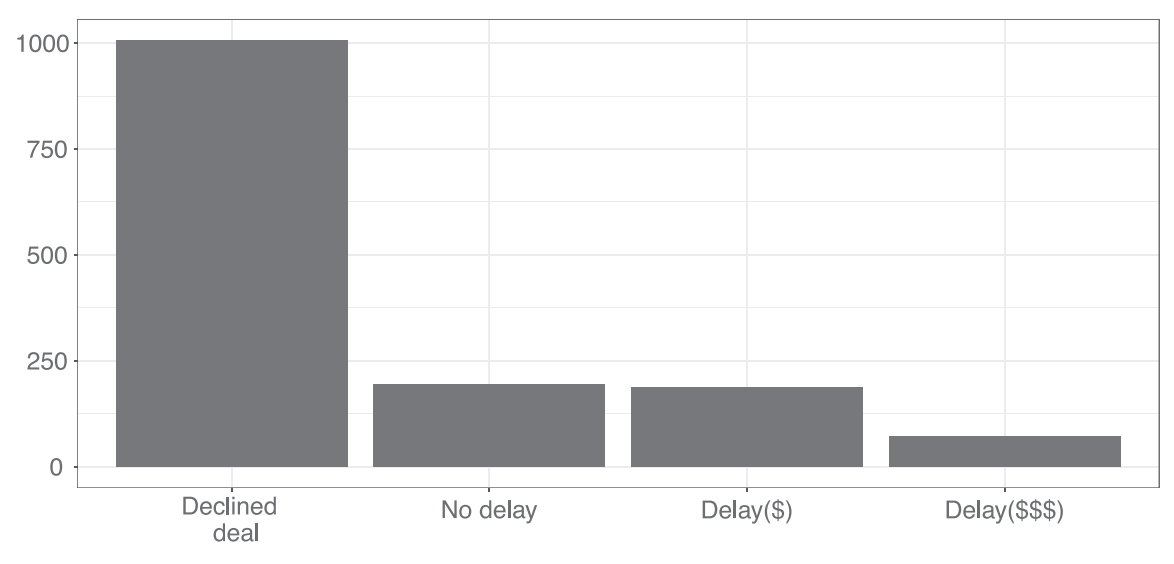

Note: Number of respondents who purchased the labeled deal level. $N=1,422$. 


\section{TABLE 4 Buyer Belief of Seller Connections Driven by Connection Signal}

\begin{tabular}{lc}
\hline Connection signaled & $0.188^{* *}$ \\
& $(0.023)$ \\
Control group outcome mean & 0.169 \\
Control group outcome std. dev. & 0.362 \\
Outcome range & $\{0,1\}$ \\
Fixed effects & Yes \\
Controls & Yes \\
Observations & 1,458 \\
\hline
\end{tabular}

Note: The specification is estimated using OLS, and includes randomization block and enumerator fixed effects, as well as controls for gender, age, education, employment status, student status, and an interaction between treatment and buyer-seller coethnicity/coreligiosity.

$\dagger p<0.1,{ }^{*} p<0.05,{ }^{* *} p<0.01$ from two-sided tests.

\section{The Impact of Political Connections and Formal Contracts on Exchange}

What is the overall impact of signaling political connections and offering formal contracts on propensities to trade? Table 5 presents the ATEs. These results first show that the impact of political connections was consistently negative (Hypothesis 1), though only approaching significance for the outcome of purchasing at all. This suggests that sellers' political connections affected the perceived risk of substandard quality of products, though the multinomial results in Online Appendix Table S12 (p. SI14) additionally indicate that connections decreased the likelihood of purchasing the more expensive delayed option as well. Importantly, these results do not take into account buyers' political connections, and might thus obscure important variation that forms around asymmetric political power. In the next section, I incorporate buyers' levels of political connections to assess if asymmetries in political connections impacted confidence in exchange.

The results in Table 5 also paint an interesting picture of the role of formal contracts. The reported estimates show that although offering formal contracts did not induce overall purchases, they did substantially boost willingness to accept the riskier delayed delivery (Hypothesis 2 ). Though this may appear at first blush to be an intuitive result, it is somewhat unexpected in Senegal's environment of weak norms of contract enforcement. That formal contracts were able to increase risky purchasing behavior by 10.4 percentage points is significant in this institutional context. This increase in exchange only occurred when the contract was a required part of the deal and not when buyers could opt for it, suggesting that formal contracts in these environments work best when sellers demonstrate self-constraint as an inherent part of the deal. Because the evidence suggests that the optional contract treatment arm was conceptually similar to not including a contract at all, I pool it with the control group to improve statistical power in the remainder of the article. Models (2) and (4) in Table 5 report these pooled results. Results remain substantively similar throughout the article with and without pooling the optional contract group.

Turning to the models' interactive terms, the results are inconclusive: Though required formal contracts appear to mitigate some of the distrust that political connections induce, the estimates are too noisy to draw conclusions. This stands in contrast to previous work that has shown that social enforcement can substitute for formal enforcement, though as I have argued above, political connections affect exchange through different channels than social enforcement mechanisms. I further parse the relationship between connections and contracts later in the article by taking buyers' political connections into account.

\section{Imbalances in Buyer-Seller Political Connections Affect Exchange}

As described above, asymmetric political power between buyers and sellers implies unequal contract enforcement privileges, and we should thus expect to observe differences in rates of exchange as a function of imbalances in the trading dyad. I therefore estimate the impact of the political connection treatment by buyers' political connections.

Figures 4(a) and 4(b) present decomposed results by buyers' and sellers' political connections for the purchased at all and purchased with delay outcomes, respectively. ${ }^{22}$ For each subfigure, I present group means in Panel A, and in Panel B report covariate-adjusted differences from linear restrictions on Equation (1).

As these figures show, the expected result of stifled purchases when sellers were politically connected did not materialize across all buyer types. Rather, exchange was stifled at a level approaching significance only for the purchase at all outcome, and only for connected buyers, who preferred to exchange with less powerful sellers. The multinomial and probit results (Online Appendices S and W, respectively; pp. SI13-SI14, SI17) lend additional support for this finding. These trades

\footnotetext{
${ }^{22}$ Online Appendix I (p. SI7) presents these results in table form.
} 
TABLE 5 Average Treatment Effects

\begin{tabular}{|c|c|c|c|c|}
\hline & \multicolumn{2}{|c|}{ Outcome: Purchased at all } & \multicolumn{2}{|c|}{ Outcome: Purchased with delay } \\
\hline & $\begin{array}{l}\text { Unpooled } \\
\text { (1) }\end{array}$ & $\begin{array}{l}\text { Pooled } \\
(2)\end{array}$ & $\begin{array}{l}\text { Unpooled } \\
\text { (3) }\end{array}$ & $\begin{array}{c}\text { Pooled } \\
(4)\end{array}$ \\
\hline Political connection signal & $\begin{array}{r}-0.053^{\dagger} \\
(0.042)\end{array}$ & $\begin{array}{c}-0.044^{\dagger} \\
(0.031)\end{array}$ & $\begin{array}{c}0.001 \\
(0.036)\end{array}$ & $\begin{array}{c}-0.013 \\
(0.027)\end{array}$ \\
\hline Required contract & $\begin{array}{c}0.047 \\
(0.043)\end{array}$ & $\begin{array}{c}0.048 \\
(0.037)\end{array}$ & $\begin{array}{l}0.104^{* *} \\
(0.037)\end{array}$ & $\begin{array}{r}0.075^{*} \\
(0.032)\end{array}$ \\
\hline Optional contract & $\begin{array}{c}-0.003 \\
(0.043)\end{array}$ & & $\begin{array}{c}0.059 \\
(0.037)\end{array}$ & \\
\hline $\begin{array}{l}\text { Political connection signal } \\
\times \text { required contract }\end{array}$ & $\begin{array}{c}0.045 \\
(0.055)\end{array}$ & $\begin{array}{c}0.035 \\
(0.048)\end{array}$ & $\begin{array}{r}-0.003 \\
(0.048)\end{array}$ & $\begin{array}{c}0.011 \\
(0.041)\end{array}$ \\
\hline $\begin{array}{l}\text { Political connection signal } \\
\times \text { optional contract }\end{array}$ & $\begin{array}{c}0.019 \\
(0.055)\end{array}$ & & $\begin{array}{r}-0.029 \\
(0.047)\end{array}$ & \\
\hline Control group outcome mean & 0.315 & 0.310 & 0.145 & 0.163 \\
\hline Control group outcome std. dev. & 0.466 & 0.463 & 0.353 & 0.370 \\
\hline Fixed effects & Yes & Yes & Yes & Yes \\
\hline Controls & Yes & Yes & Yes & Yes \\
\hline Observations & 1,458 & 1,458 & 1,458 & 1,458 \\
\hline
\end{tabular}

Note: Each specification is estimated using OLS. The two outcomes are binary indicators for whether a buyer purchased any phone credit option or an option with delayed delivery. Specifications include randomization block and enumerator fixed effects, and controls for gender, age, education, employment status, student status, and interactions between treatments and buyer-seller coethnicity/coreligiosity. $\dagger p<0.1,{ }^{*} p<0.05,{ }^{* *} p<0.01$ from two-sided tests and preregistered one-sided tests.

represent the cases in which buyers are most powerful and least at-risk, in that connected buyers maintain disproportionate political power and recourse options if the deal were to go awry. Indeed, in the endline survey, when asked what they would have done had the terms of the exchange been violated, buyers with political connections were more likely than unconnected buyers to state that they would pursue recourse options, more likely to seek formal recourse options in hypothetical contract disputes, and more likely to believe in the preferential enforcement power of the state (see Online Appendix U, p. SI15).

Interestingly, there was no similar effect among unconnected buyers. This may be due to the generally low purchase rates, which suggest that these estimates are perhaps a lower bound for unconnected types. This may also be due to lack of political knowledge and experience: I show in Online Appendix T (pp. SI14-SI15) that politically unconnected buyers were less likely to correctly update about sellers' political connections, and provide suggestive evidence that some unconnected buyers mistakenly believed that unconnected sellers were connected. These inferential issues may help to account for the lack of effect among unconnected buyers.
Of course, buyers' political connections were not randomized as part of the experiment, and these connections may be indicative of other traits that are also associated with propensities to trade. However, as I show in Online Appendix K (p. SI8), buyers' political connections are not strongly correlated with such variables, and the results throughout the article are robust to including interactive treatment controls for these potential confounders (see Online Appendix V, p. SI16). This lack of correlation fits the case of Senegal, where possessing connections is not necessarily a signal of other forms of privilege such as wealth; this is especially true in the middleto lower income neighborhoods where I implemented the field experiment.

Overall, these results lend only partial support to Hypothesis 3: Although connected buyers were less likely to exchange with connected sellers, there was no similar decrease for unconnected buyers. Thus, at least among connected buyers, sellers' political connections stifled trade by enhancing the risk of receiving substandard quality goods and not the risk of nondelivery, though this latter estimate may be limited by the relatively low takeup of the offer. Although not in the scope of this article's theory, I speculate that this might 
(a) Purchased at all

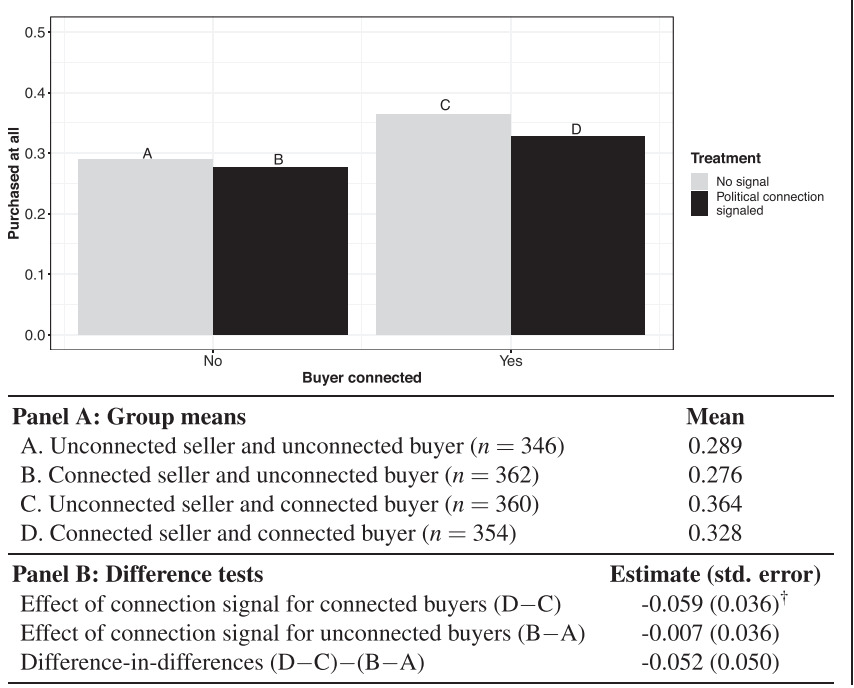

(b) Purchased with delay

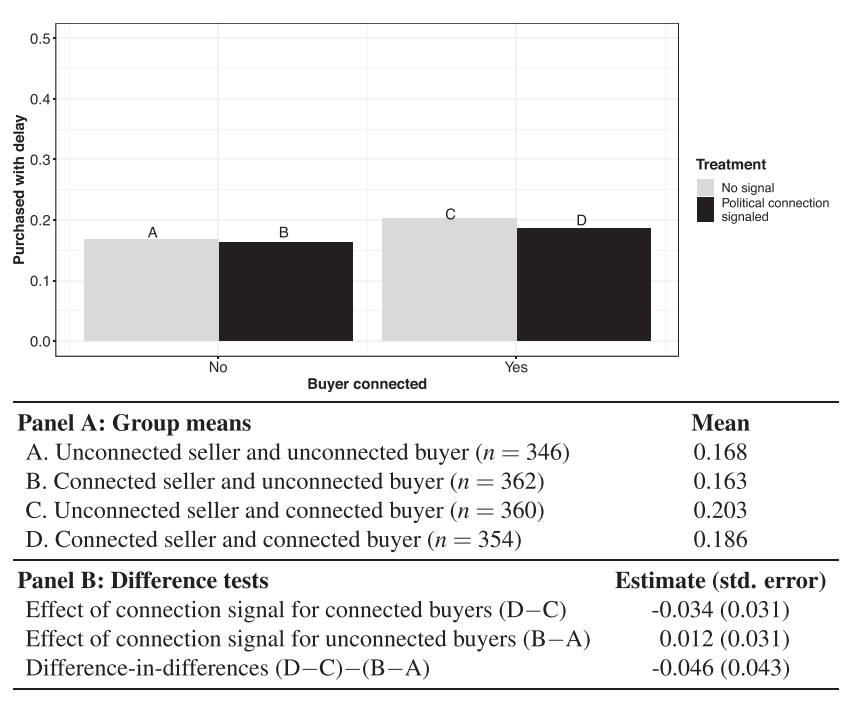

Note: Panels A present group means for the four subgroups. Panels B present differences estimated using OLS with linear restrictions. The two outcomes are binary indicators for whether a buyer purchased any phone credit option or an option with delayed delivery. Specifications include randomization block and enumerator fixed effects, and controls for gender, age, education, employment status, student status, and interactions between treatments and buyer-seller coethnicity/coreligiosity.

$\dagger p<0.1,{ }^{*} p<0.05,{ }^{* *} p<0.01$ from two-sided tests and pre-registered one-sided tests.

also be due to risk tolerances: Political connections may affect the most risk-averse buyers, whereas among more risk-seeking buyers, political connections are not enough to deter purchasing the more lucrative delayed options.

\section{Formal Contracts Primarily Protect Connected Buyers}

The above ATE estimates showed that offering formal contracts increased the probability of the riskiest types of exchange. But how do formal contracts operate in the context of important political connections? In a world where the ability to enforce contracts is biased toward the politically connected, buyers may differentially value formal contracts based on their level of political connectivity. To test this claim, I estimate the impact of the formal contract treatment by buyers' political connections.

Figures 5(a) and 5(b) present these results, which reveal a stark pattern: The effect of formal contracts on propensities to trade is driven primarily by connected buyers, both for purchasing at all as well as purchasing with delay (Hypothesis 4). ${ }^{23}$ Among unconnected buy-

${ }^{23}$ I provide the corresponding model output in table form in Online Appendix I (p. SI17). ers, formal contracts had no impact on the purchased at all outcome, and a small impact approaching significance on the purchased with delay outcome. As with the previous models, these results are robust to interacting treatment with potential confounders as well as to controlling for predictors of social enforcement. These findings suggest that, although formal contracts may improve confidence in exchange, they do so for a particular subset of the population: those who can be confident in their ability to sway enforcement in their favor during disputes (see Online Appendix U, p. SI15). Formal contracts may thus not enhance the recourse options or protect those who are otherwise powerless; they may be a viable enforcement solution only for those who are already most privileged in societies with selectively enforced rule of law.

\section{Alternative Hypotheses and Robustness}

No Evidence of Social Enforcement Via In-Group Bias or Findability Mechanisms. As shared social identity has been shown to reduce transaction costs (Sanchez de la Sierra 2018; Grimard 1997), buyers with similar social networks to sellers-in Senegal proxied by shared ethnic group or religious network-may have experienced a greater sense of confidence and security in the 


\section{FIGURE 5 Effects of Formal Contracts by Buyers' Connections}

(a) Purchased at all

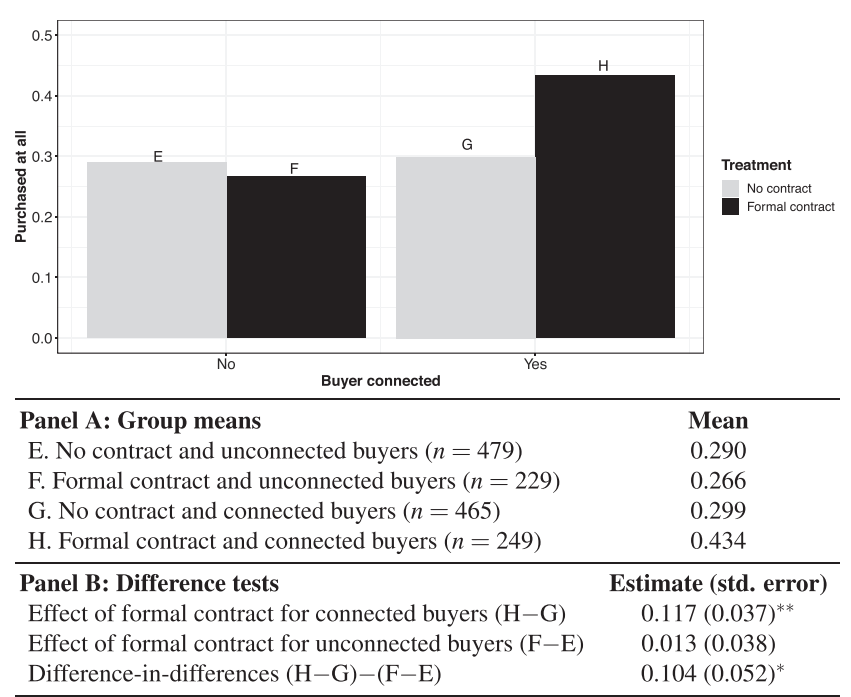

(b) Purchased with delay

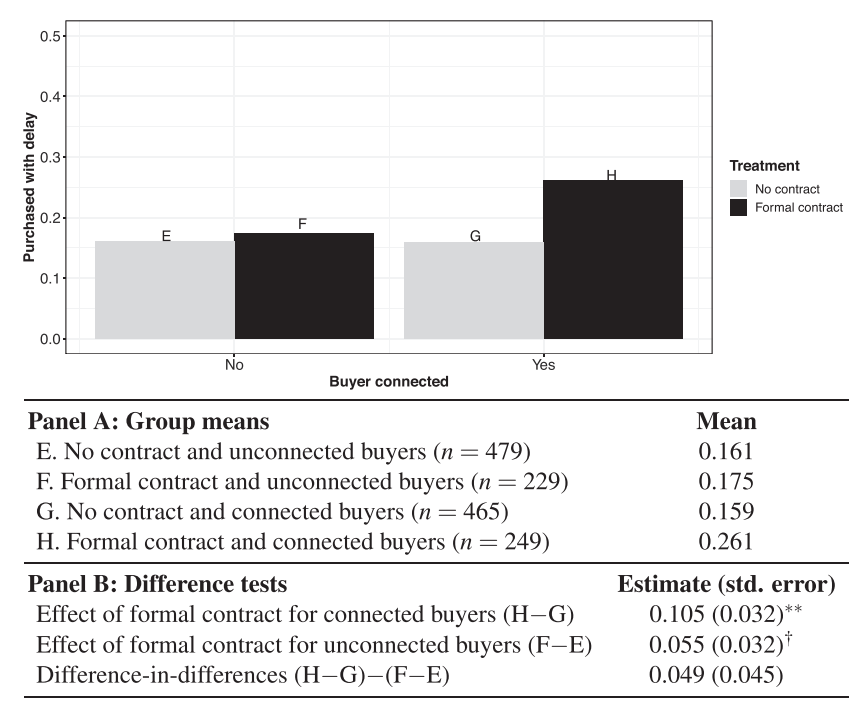

Note: Panels A present group means for the four subgroups. Panels B present differences estimated using OLS with linear restrictions. The two outcomes are binary indicators for whether a buyer purchased any phone credit option or an option with delayed delivery. Specifications include randomization block and enumerator fixed effects, and controls for gender, age, education, employment status, student status, and interactions between treatments and buyer-seller coethnicity/coreligiosity.

$\dagger p<0.1,{ }^{*} p<0.05,{ }^{* *} p<0.01$ from two-sided tests and preregistered one-sided tests.

deal compared to out-group members. This may have also moderated treatment; for example, although political connections may be off-putting to buyers in the aggregate, they could be perceived as valuable if the seller who has them belongs to the same in-group network. As the estimates in the preceding sections as well as in Online Appendix L (p. SI9) show, however, results are robust to interactive controls between treatments and buyer-seller coethnicity and coreligiosity. I similarly rule out the possibility of findability mechanisms (e.g., Miguel and Gugerty 2005; Habyarimana et al. 2007), discussed in greater detail in Online Appendix M (pp. SI9-SI10).

\section{Addressing Confounding Interpretations of Seller Polit- ical Connections. A potential concern is that by signal- ing political connections, sellers transmitted information about their quality or competence rather than induced considerations about the probability of contract dispute and enforcement. Questions in both the transaction stage and the endline survey attempted to measure the valid- ity of this concern. First, at the end of each transaction, sellers completed a survey in which they recorded whether buyers asked follow-up questions, as well as their subjective measures of buyers' levels of suspicion and po-}

liteness. Second, the endline survey asked buyers about their perceptions of sellers' competence and trustworthiness. ${ }^{24}$ I regress these measures of perceived quality on the treatment indicators, and present the results in Table 6.

The findings show that treatment did not drive respondents' opinions of sellers' competence, nor did sellers sense a differential level of suspicion or politeness based on treatment status. However, buyers asked a higher number of follow-up questions in both the connection and contract treatment groups. Examining the nature of these questions more closely, buyers typically asked logistical questions, such as where to sign and date, as well as some questions regarding the terms of the contract. Questions related to the political connection were typically about the nature of sellers' work at councils and whether they were still based there. The sum of evidence suggests that treatment effects were not driven by concerns over quality or competence.

\footnotetext{
${ }^{24}$ To reduce social desirability bias, the endline survey was conducted by different enumerators than the transaction phase.
} 
TABLE 6 Quality Measures from Buyers and Sellers

\begin{tabular}{|c|c|c|c|c|c|c|c|c|c|c|}
\hline & \multicolumn{4}{|c|}{ Buyer's perception of... } & \multicolumn{6}{|c|}{ Seller's perception of... } \\
\hline & \multicolumn{2}{|c|}{ Seller's competence } & \multicolumn{2}{|c|}{ Trustworthiness } & \multicolumn{2}{|c|}{ \# of questions asked } & \multicolumn{2}{|c|}{ Buyer's politeness } & \multicolumn{2}{|c|}{ Buyer's suspicion } \\
\hline & (1) & $(2)$ & (3) & $(4)$ & (5) & $(6)$ & (7) & (8) & (9) & (10) \\
\hline Political connection signal & $\begin{array}{r}-0.023 \\
(0.032)\end{array}$ & $\begin{array}{r}-0.035 \\
(0.038)\end{array}$ & $\begin{array}{r}-0.004 \\
(0.050)\end{array}$ & $\begin{array}{r}-0.026 \\
(0.059)\end{array}$ & $\begin{array}{c}0.038 \\
(0.028)\end{array}$ & $\begin{array}{l}0.064^{\dagger} \\
(0.033)\end{array}$ & $\begin{array}{c}0.050 \\
(0.043)\end{array}$ & $\begin{array}{c}0.040 \\
(0.050)\end{array}$ & $\begin{array}{c}0.063 \\
(0.069)\end{array}$ & $\begin{array}{c}0.076 \\
(0.081)\end{array}$ \\
\hline Formal contract & $\begin{array}{c}0.044 \\
(0.034)\end{array}$ & $\begin{array}{c}0.026 \\
(0.045)\end{array}$ & $\begin{array}{c}0.073 \\
(0.052)\end{array}$ & $\begin{array}{c}0.040 \\
(0.070)\end{array}$ & $\begin{array}{c}0.033 \\
(0.030)\end{array}$ & $\begin{array}{r}0.072^{\dagger} \\
(0.039)\end{array}$ & $\begin{array}{r}-0.046 \\
(0.045)\end{array}$ & $\begin{array}{c}-0.061 \\
(0.060)\end{array}$ & $\begin{array}{c}0.006 \\
(0.072)\end{array}$ & $\begin{array}{c}0.027 \\
(0.096)\end{array}$ \\
\hline $\begin{array}{l}\text { Political connection signal } \\
\times \text { formal contract }\end{array}$ & & $\begin{array}{c}0.035 \\
(0.058)\end{array}$ & & $\begin{array}{c}0.066 \\
(0.091)\end{array}$ & & $\begin{array}{r}-0.077 \\
(0.051)\end{array}$ & & $\begin{array}{c}0.029 \\
(0.078)\end{array}$ & & $\begin{array}{r}-0.040 \\
(0.126)\end{array}$ \\
\hline Control group outcome mean & 3.603 & 3.603 & 2.485 & 2.485 & 0.952 & 0.952 & 3.476 & 3.476 & 0.884 & 0.884 \\
\hline Control group outcome std. dev. & 0.540 & 0.540 & 0.827 & 0.827 & 0.753 & 0.753 & 0.940 & 0.940 & 1.25 & 1.25 \\
\hline Fixed effects & Yes & Yes & Yes & Yes & Yes & Yes & Yes & Yes & Yes & Yes \\
\hline Controls & Yes & Yes & Yes & Yes & Yes & Yes & Yes & Yes & Yes & Yes \\
\hline Observations & 1,458 & 1,458 & 1,458 & 1,458 & 1,458 & 1,458 & 1,458 & 1,458 & 1,458 & 1,458 \\
\hline
\end{tabular}

Note: Specifications are estimated using OLS, and includes randomization block and enumerator fixed effects, as well as controls for gender, age, education, employment status, student status, and interactions between treatments and buyer-seller coethnicity/coreligiosity. $\dagger p<0.1,{ }^{*} p<0.05,{ }^{* *} p<0.01$ from two-sided tests.

\section{Conclusion}

In areas where rule of law is selectively enforced, political connections can produce moral hazard in exchange and complicate the function of formal enforcement institutions. Using evidence from a field experiment in a real trading environment, this article demonstrates that asymmetric political connections can affect basic forms of exchange. By showing that political connections can prevent exchange where it would otherwise occur, this study suggests that research that observes outcomes conditional on trade may be clouded by sample biases and excessive focus on the intensive rather than extensive margin. And although existing work focuses on ascriptive predictors of social enforcement such as coethnicity, I show that political connections can explain patterns of trade even when accounting for social enforcement. The findings of this article suggest that low-level political connections of both sellers and buyers merit consideration for understanding patterns of private-sector growth in developing countries.

This article also provides causal evidence that statebacked formal contracts can boost confidence in trade, even in environments with weak rule of law and contract enforcement. Upon closer inspection, however, these results also highlight fundamental inequalities in developing democracies with uneven rule of law: Formal contracts do not protect all buyers equally. Rather, formal contracts primarily protect the claims of the politically powerful. This article thus implies the limits of ad hoc legal solutions in the presence of broader political inequalities. Counterintuitively, increasing the availability of formal contracts may intensify economic inequalities and market segmentation.

This project represents an initial, partial equilibrium approach to identify the impact of political connections on daily types of economic exchange in modern developing markets. Future work would benefit from examining different types of markets and connections in order to form a unified theory across firms, individuals, and sectors-including where reputational considerations significantly structure markets-and should strive toward testing the general equilibrium implications. Although this article empirically distinguishes between core components of seller moral hazard-the risks of substandard quality products and of nondeliveryfuture research could more explicitly theorize and test the underpinnings of this distinction. Finally, although this field experiment highlighted the impact of political connections and formal contracts, more work is needed to identify the precise behavioral mechanisms behind this impact, including the psychological foundations of their effects.

I argue that the theory and findings of this article are likely to apply to contexts where enforcement institutions are weak and personal connections moderate access to the state. Indeed, these conditions characterize the bulk of the world's developing democracies. In societies where a state apparatus exists for enforcing property rights and contracts, and where business occurs at such a scale that social enforcement mechanisms alone are not viable, people must use a mixture of formal and informal mechanisms to enforce their deals. This article provides evidence for how informal networks of political influence 
in these places can impede the function of formal institutions in shaping private-sector economic development. These results also help to explain how legal institutions facilitating contract enforcement can coexist with rising inequality and lagging development.

As emerging markets continue to develop, problems stemming from unequal political influence in the private sector may grow more amplified as well. This can have distributive consequences for ordinary citizens. When only the politically connected can contract with confidence and when those without connections are averse to exchanges with moral hazard, distinct economic networks can develop around differently privileged groups, resulting in suppressed overall levels of trade and inefficiencies. Understanding how informal connectionspolitical and otherwise-moderate institutional access (e.g., Slough 2020) and interact with state institutions for enforcement will thus be particularly important for private-sector growth in the coming years.

In addition to its theory and findings, this project contributes a design-based technique to examine these important questions. If ethical standards are exhaustively met, creating a business offers political scientists unprecedented experimental control and realism, which has implications for the study of business and politics across a variety of settings.

\section{References}

Acemoglu, Daron, and Simon Johnson. 2005. "Unbundling Institutions." Journal of Political Economy 113(5): 949-95.

Arrow, Kenneth J. 1972. "Gifts and Exchanges." Philosophy \& Public Affairs 1(4): 343-62.

Baker, George, Robert Gibbons, and Kevin J Murphy. 2002. "Relational Contracts and the Theory of the Firm." Quarterly Journal of Economics 117(1): 39-84.

Bhandari, Abhit. 2020. "Firm Strategies, Weak Rule of Law: Contract Enforcement in Informal Environments." Working Paper https://abhitbhandari.com/s/Enforcement_ Senegal.pdf. Accessed May 29, 2020.

Cruise, O, 'Brien, Donal Brian. 1971. The Mourides of Senegal. Oxford: Clarendon Press.

Dixit, Avinash. 2003. "Trade Expansion and Contract Enforcement." Journal of Political Economy 111(6): 1293-1317.

Faccio, Mara. 2006. "Politically Connected Firms." American Economic Review 96(1): 369-86.

D Fearon, James, and David D Laitin. 1996. "Explaining Interethnic Cooperation." American Political Science Review 90(04): 715-35.

Fisman, Raymond. 2001. "Estimating the Value of Political Connections." American Economic Review 91(4): 10951102.
Frye, Timothy. 2004. "Credible Commitment and Property Rights: Evidence from Russia." American Political Science Review 98(03): 453-66.

Gottlieb, Jessica. 2017. "Explaining Variation in Broker Strategies: A Lab-in-the-Field Experiment in Senegal." Comparative Political Studies 50(11): 1556-92.

Greif, Avner. 1989. "Reputation and Coalitions in Medieval Trade: Evidence on the Maghribi Traders." The Journal of Economic History 49(4): 857-82.

Grimard, Franque. 1997. "Household Consumption Smoothing Through Ethnic Ties: Evidence from Cote d'Ivoire." Journal of Development Economics 53(2): 391422.

Habyarimana, James, Macartan Humphreys, Daniel N Posner, and Jeremy M Weinstein. 2007. "Why Does Ethnic Diversity Undermine Public Goods Provision?" American Political Science Review 101(4): 709-25.

Holland, Alisha C. 2016. "Forbearance." American Political Science Review 110(2): 232-46.

Joireman, Sandra Fullerton. 2001. "Inherited Legal Systems and Effective Rule of Law: Africa and the Colonial Legacy." The Journal of Modern African Studies 39(4): 571-96.

Ijaz Khwaja, Asim, and Atif Mian. 2005. "Do Lenders Favor Politically Connected Firms? Rent Provision in an Emerging Financial Market." The Quarterly Journal of Economics 120(4): 1371-1411.

Kondylis, Florence, and Mattea Stein. 2018. "The Speed of Justice." World Bank Policy Research Working Paper: https://elibrary.worldbank.org/doi/abs/10.1596/ 1813-9450-8372. Accessed June 1, 2018.

Koter, Dominika. 2013. "Urban and Rural Voting Patterns in Senegal: The Spatial Aspects of Incumbency, c. 19782012." The Journal of Modern African Studies 51(4): 65379.

Lu, Haitian, Hongbo Pan, and Chenying Zhang. 2015. "Political Connectedness and Court Outcomes: Evidence from Chinese Corporate Lawsuits." The Journal of Law and Economics 58(4): 829-61.

Miguel, Edward, and Mary Kay Gugerty. 2005. "Ethnic Diversity, Social Sanctions, and Public Goods in Kenya." Journal of Public Economics 89(11-12): 2325-68.

North, Douglass C. 1990. Institutions, Institutional Change and Economic Performance. Cambridge: Cambridge University Press.

North, Douglass C. 1991. "Institutions." Journal of Economic Perspectives 5(1): 97-112.

C North, Douglass, and Barry R Weingast. 1989. "Constitutions and Commitment: The Evolution of Institutions Governing Public Choice in Seventeenth-Century England." Journal of Economic History 49(04): 803-32.

Poppo, Laura, and Todd Zenger. 2002. "Do Formal Contracts and Relational Governance Function as Substitutes or Complements?" Strategic Management Journal 23(8): 707-25.

Posner, Daniel N. 2004. "Measuring Ethnic Fractionalization in Africa." American Journal of Political Science 48(4): 84963.

Roberts, Brian E. 1990. "A Dead Senator Tells No Lies: Seniority and the Distribution of Federal Benefits." American Journal of Political Science 34(1): 31-58. 
Sanchez de la Sierra, Raul. 2018. "When Formal Contract Fail.” Working Paper: https://raulsanchezdelasierra. files.wordpress.com/2018/02/

when-formal-contracts-fail-online1.pdf. Accessed April 25, 2018.

Slough, Tara. 2020. "Bureaucrats Driving Inequality in Access: Experimental Evidence from Colombia." Working Paper: https://taraslough.github.io/assets/pdf/colombia_audit.pdf. Accessed May 26, 2020.

Szakonyi, David. 2018. "Businesspeople in Elected Office: Identifying Private Benefits from Firm-Level Returns." American Political Science Review 112(2): 322-38.

Williamson, Oliver E. 1985. The Economic Institutions of Capitalism. New York: Simon and Schuster.

\section{Supporting Information}

Additional supporting information may be found online in the Supporting Information section at the end of the article.

Appendix A : Business registration document Appendix B : Transaction protocol

Appendix C : Formal contract language

Appendix D : Main results when outcome is coded from 0 to 3
Appendix E : Balance

Appendix F : Summary statistics for control variables

Appendix G : Attrition not predicted by treatment

Appendix H : Contract choice not motivated by political connections

Appendix I : Corresponding model output for Figures $4 a, 4 b, 5 a$, and $5 b$

Appendix J : Trust in courts across Africa

Appendix K : Correlates of buyers' political connections Appendix L : Heterogeneous effects by in-group

Appendix M : Heterogeneous effects by district match

Appendix N : Treatments did not raise buyers' suspicions Appendix $\mathbf{O}$ : No overreporting of connections based on political connections

Appendix P : Deviations from pre-analysis plan

Appendix Q : Solutions to commitment problems in trade

Appendix R : Social enforcement mechanisms in Senegal

Appendix $\mathrm{S}$ : Multinomial logistic regression results

Appendix T : Variation in perceived seller connectivity by buyer type

Appendix U : Connected buyers more likely to seek recourse

Appendix V : Interactive controls

Appendix W : Probit results 